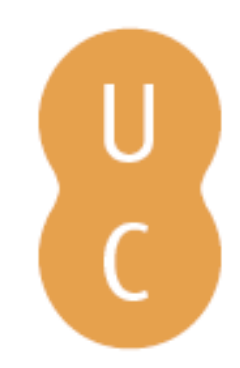

\title{
nombalina
}

\section{A Medeia de Eurípides e o espaço trágico de Corinto}

Autor(es): $\quad$ Fialho, Maria do Céu

Publicado por: Imprensa da Universidade de Coimbra; Universidad de Valladolid

URL

persistente: URI:http://hdl.handle.net/10316.2/32292

DOI: DOI:http://dx.doi.org/10.14195/978-989-26-0472-5_1

Accessed : $\quad$ 26-Apr-2023 07:20:28

A navegação consulta e descarregamento dos títulos inseridos nas Bibliotecas Digitais UC Digitalis, UC Pombalina e UC Impactum, pressupõem a aceitação plena e sem reservas dos Termos e Condições de Uso destas Bibliotecas Digitais, disponíveis em https://digitalis.uc.pt/pt-pt/termos.

Conforme exposto nos referidos Termos e Condições de Uso, o descarregamento de títulos de acesso restrito requer uma licença válida de autorização devendo o utilizador aceder ao(s) documento(s) a partir de um endereço de IP da instituição detentora da supramencionada licença.

Ao utilizador é apenas permitido o descarregamento para uso pessoal, pelo que o emprego do(s) título(s) descarregado(s) para outro fim, designadamente comercial, carece de autorização do respetivo autor ou editor da obra.

Na medida em que todas as obras da UC Digitalis se encontram protegidas pelo Código do Direito de Autor e Direitos Conexos e demais legislação aplicável, toda a cópia, parcial ou total, deste documento, nos casos em que é legalmente admitida, deverá conter ou fazer-se acompanhar por este aviso.

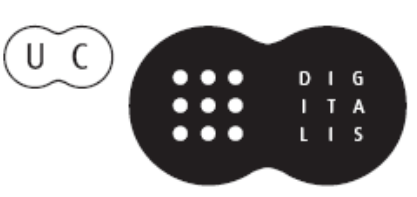


Emilio Suárez de la Torre

Maria do Céu Fialho

(Coordinadores)

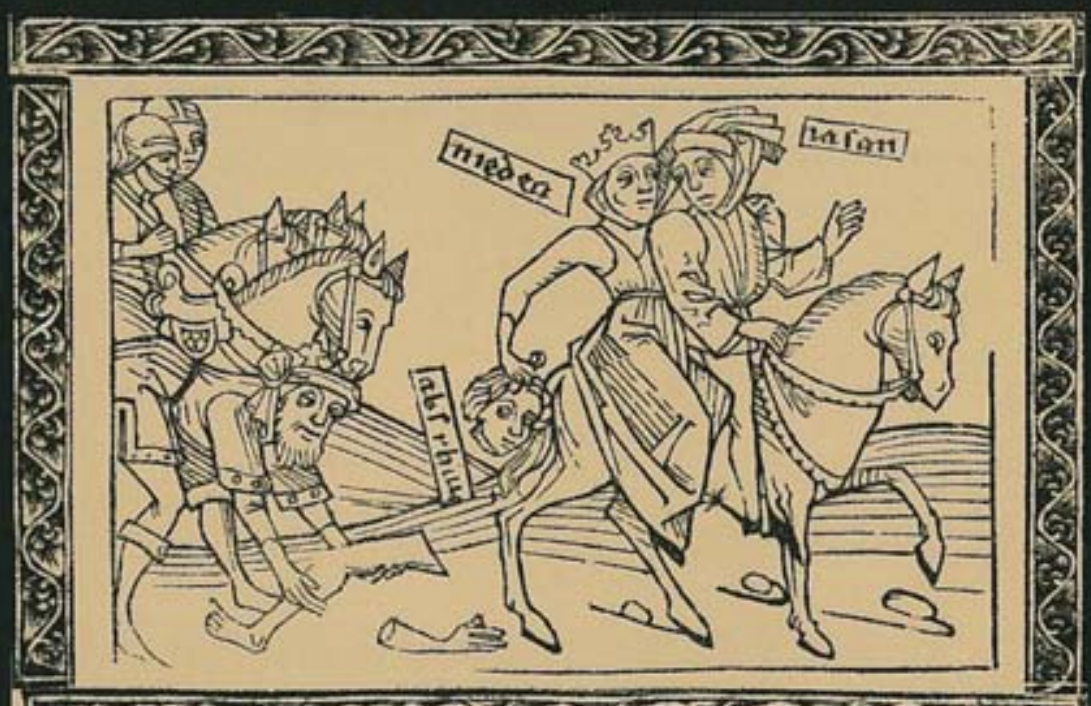

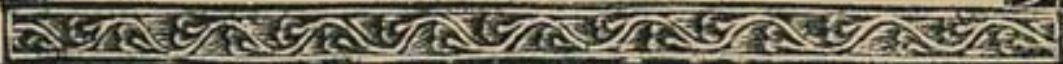

\section{BAJO EL SIGNO DE MEDEA}

\section{SOB O SIGNO DE MEDÉIA}




\title{
A Medeia de Eurípides e o espaço trágico de Corinto
}

\author{
MARIA do CÉU FIALHo \\ Universidade de Coimbra
}

A Primavera de 431 a.C., em que Eurípides apresenta a concurso a sua Medeia, nas Dionísias Urbanas, marca o início de uma guerra há muito anunciada entre as duas potências à volta das quais se satelitizaram as cidades-estado da Hélade.

O mito dramatizado por Eurípides pertence a uma tradiçăo narrativa mais vasta e antiquíssima -a da empresa dos Argonautas, até terras longínquas do Nordeste, em busca do Velo de Ouro, guardado por uma serpente inexpugnável, no domínio de um monarca cioso do seu tesouro. Tal tradiçăo inscreve-se no modelo de outras narrativas de perigosas viagens marinhas, encetadas à conquista de um tesouro mágico, inacessível, existentes em antigas culturas do Mediterrâneo Oriental. Com esta, em particular, se cruza o motivo tăo típico do conto popular do enamoramento da jovem princesa pelo estrangeiro, que há-de vencer provas, e que da princesa recebe oculta ajuda.

$\mathrm{O}$ convívio de tais narrativas e o sinal da anterioridade deste mito em relaçăo ao dos errores de Ulisses atesta-o o poeta da Odisseia (12. 69-70):

Por ali só uma nau passou, das que navegam no alto mar:

a nau Argo, por todos cantada, ao regressar da terra de Aetes...

A presença e acçāo, na narrativa desta aventura, por parte da jovem princesa, tem testemunhos deste bastante cedo. O sucesso da empresa é de carácter praticamente impossível e pode depreender-se do fragmento 11 West de Mimnermo que ele se ficou a dever a factores de origem alheia à força dos heróis envolvidos na demanda. Esse factor de sucesso foi Medeia, a princesa filha de Aetes, sobrinha de Circe, que Hesíodo, Th. 992-1002, dá como trazida para Iolco por vontade divina. 
Nota W. Allan ${ }^{(1)}$ que tanto em Hesíodo como em Píndaro, P. 4. 71251, que alude aos poderes mágicos da princesa, se supōe uma natureza imortal de Medeia - análoga, afinal, à da Circe homérica - enquanto Eurípides pôe diante dos espectadores uma figura feminina profundamente humana. Aí reside, pois, a grande originalidade do dramaturgo, que modela, a partir dos dados da tradiçăo - incluindo a tradiçâo dramatúrgica mais recente- um carácter complexo e extraordinário e lhe dá vida e urgência em responder à situaçăo trágica que o envolve na terra estrangeira de Corinto ${ }^{(2)}$.

Diversas têm sido as leituras da ethopoiia de Eurípides no que diz respeito à personagem de Medeia, com o objectivo de procurar entender o sentido da peça ou sustentar uma sua leitura. $\mathrm{O}$ entendimento da protagonista como a feiticeira bárbara que, cumprida a vingança desmedida, regressa à sua dimensáo original, por sobre o rasto de destruiçăo que deixa atrás de si, radica na interpretaçăo defendida por Page ${ }^{(3)}$ e condensada na sua já famosa afirmaçăo: "Because she was a foreigner, she could kill her children; because she was a witch she could escape in a chariot". Tal perspectiva, se, porventura, colhe apoio em posteriores leituras da peça, tem vindo, nas últimas décadas, a ser refutada à medida que se impóe a compreensăo da peça como documento cultural, no contexto de uma problematizaçăo do confronto crítico identidade-alteridade - é o caso, já, em parte, do estudo de Kovacs ${ }^{(4)}$ e, sobretudo, do livro já citado de W. Allan.

Na mesma medida, também os Genderstudies têm prestado nova atenção valorativa à figura da protagonista. Ilustram esta última tendência, entre outros, os trabalhos de Elisabeth Bryson Bongie ${ }^{(5)}$ ou Shirley

(1) W. Allan, Euripides: Medea, London, 2002, pp. 17 sqq.

(2) Outros tragediógrafos, como Sófocles e Néofron, exploraram também dramaticamente este mito. Sobre esta matéria, em especial sobre a questāo da intertextualidade Eurípides-Néofron veja-se, entre outros, B. Manuwald, "Der Mord an den Kindern" WS 17, 1983, 27-61 e A.M. Michelini, Euripides and the Tragic Tradition, Madison, 1989. Durante muito tempo pensou-se que Néfron tinha vivido e composto tragédia no séc. IV a.C. O trabalho de Manuwald tem o mérito de deitar nova luz sobre o assunto: a relaçăo entre a força do thymos de Medeia e o infanticídio é comum aos dois tragediógrafos, consoante conclui da análise do frg. 2 de Néofron; o tratamento euripidiano representa, todavia, segundo aquele autor, um refinamento do dramaturgo em relaçăo a um motivo já tratado anteriormente. De facto, quando Aristóteles, na sua Poética, 1453b 19, refere o infanticídio cometido por Medeia, é à peça de Eurípides que se refere, como sendo do dramaturgo o tratamento, por excelência, do tema.

(3) D.L. Page, Medea. The Plays of Euripides, Oxford, Oxford Univ. Press p. xxi.

(4) D. Kovacs, "Zeus in Euripides' Meded" AJPh 114, 1993, 45-70.

(5) "Heroic Elements in the Medea of Euripides", TAPhA 107, 1977, 27-56. 
Barlow ${ }^{(6)}$. Para tal contribuiu também a própria recepção, de extrema riqueza, aliás, de Medeia no teatro e na narrativa romanesca ou cinematográfica contemporâneas ${ }^{(7)}$.

Por seu turno, o famoso livro de Knox sobre o temperamento heróico dos protagonistas sofoclianos ${ }^{(8)}$ e a sua estatura excepcional, que os isola como figuras capazes de decisōes extremas, de emoçōes extremas, marcados por uma authadia e uma autarkeia que os leva a nẩo saber, jamais, ceder, veio a sugerir novo caminho para um outro olhar sobre Medeia, com resultados apreciáveis. É que esta é, também, uma personagem de emoçổes e paixốes excepcionais, de um thymos que lembra o dos protagonistas sofoclianos, incapaz de ceder, no infortúnio e na crise, em nome de uma rasteira sobrevivência. Vêm nesta linha os trabalhos do próprio $\mathrm{Knox}^{(9)}$, ou de Friedrich ${ }^{(10)}$, autor bastante sensível ao tratamento euripidiano da força e manifestaçōes do thymos da protagonista.

Eurípides faz eco, na sua dramaturgia, de discussốes filosóficas do tempo, nomeadamente daquelas em que a polémica se instalou com novos ensinamentos e perspectivas relativistas dos sofistas. Tal eco é perceptível sobretudo naquelas peças que contêm vivas cenas de agon entre personagens em confronto, ou naquelas $\mathrm{em}$ que o discurso de persuasão recorre aos instrumentos e técnicas de argumentação ensinados na ágora. Medeia năo tem sido encarada como um exemplo ilustrativo desse aspecto da criaçảo euripidiana. Constitui, por isso, uma via inovadora de acesso ao texto a que foi tomada por Rickert ${ }^{(11)}$, que pondera o peso do possível intertexto, constituído pela posiçâo de Sócrates (de acordo com Platāo, Protágoras, 352b), quanto às consequências do conflito entre emoçáo $\mathrm{e}$ razão que leva o homem à akrasia, decorrente da consciência da decisão

(6) "Stereotype and Reversal in Euripides' Medea", GơR 36, 1989, 158-171.

(7) Significativo, quanto à riqueza imensa da vitalidade deste mito, é o livro de D. Mimoso-Ruiz, Médée antique et moderne. Aspects rituels et socio-politiques d'un mythe, Paris, 1982, bem como a preciosa obra, em dois volumes, editada por A. López e A. Pociña, Medeas. Versiones de ten mito desde Grecia hasta hoy, vol. I-II, Granada, 2002.

(8) B.M.W. Knox, The Heroic Temper. Studies in Sophoclean Tragedy, Berkeley, 1964.

(9) "The Medea of Euripides" YCS 25, 1977, 193-225. M.H. da Rocha Pereira, Euripides. Medeia, introd. versão do grego e notas, Coimbra, Instituto Nacional de Investigaçăo Científica 1991, pp. 18-19, refere o citado trabalho e a produtiva comparaçăo, feita pelo autor, entre Medeia e Ajax, para, apoiado em exemplos de carácter linguístico, salientar alguns traços de carácter entre os protagonistas das duas peças.

(10) R. Friedrich, "Medea apolis: on Euripides' Dramatization of the Crisis of the Polis", in A. Sommerstein, S. Hallliwell, J. Henderton, B. Zimmermann (eds.) ,Tragedy, Comedy and the Polis, Bari, 1993.

(11) G.A. Rickert, "Akrasia in Euripides' Meded" HSCPh 91, 1987, 91-117. 
que é justa e da incapacidade de a tomar, por motivos de ordem emocional.

A posiçāo de Rickert é prudente, já que refuta uma adesão, por parte de Eurípides, ilustrada na figura de Medeia, à perspectiva socrática, pois o thymos de Medeia nāo envolve apenas sentimentos fortes, mas valores ${ }^{(12)}$ e, segundo o autor, os famosos bouleumata, invocados no grande monólogo, de que me nẩo vou ocupar aqui, por nẫo se enquadrar a discussão de tal assunto nos objectivos deste trabalho, não implicam decisōes absolutamente marcadas por um "moral inside". Idêntica direcção toma o excelente trabalho, também publicado neste volume, de Henar Zamora Salamanca.

$\mathrm{Na}$ inversa proporçăo da leitura desvalorizadora ou valorizadora do comportamento de Medeia se valoriza positiva ou negativamente o comportamento de Jasão.

Devemos entender que a questăo da construçăo da acçăo dramática da peça e do modo como nela o poeta vai delineando o perfil da protagonista, envolvido na situaçăo trágica, é complementar de uma outra -a do porquê da tessitura da acção trágica desta maneira e não de maneira diversa. Ao formularmos esta questāo estamos a interrogar-nos sobre o sentido da peça e intencionalidade do autor.

Um mito, para manter a sua identidade, necessita conservar um núcleo fixo que permita o reconhecimento, pelo receptor, de que é esse mesmo mito que está em causa, ficando aberto ao narrador, lato sensu, um campo de inovaçăo ou reconfiguração, para além desse núcleo, onde ele pổe em jogo a sua particular experiência e percepçāo de vivência do tempo humano - para o caso, do tempo trágico. No gesto mimético que preside à sua criaçẩo há-de articular um jogo de referências que tornem a sua mensagem apreensível ao receptor - já que de um acto comunicacional se trata- e que permitam a este, ao seguir as referências desse jogo, em que pōe e investe a sua própria capacidade de compreensão do mundo, tocar a intencionalidade do criador, sabendo, ao mesmo tempo, que esse encontro único se dá num determinado mito — para o caso, no mito de Medeianaquela representação específica de tempo e acção humanos, como Eurípides e nâo outro a propōe.

Da tradiçăo pré-euripidiana em que Medeia é referida, saliente-se a narrativa de Píndaro, na Pítica 4. Aí Medeia surge como a feiticeira

(12) Op. cit., p. 104. 
enfeitiçada —os pharmakoi que fornece a Jasăo para vencer as provas impostas por Aetes são fruto da sedução de uma Persuasão particular. Afrodite ensinou a Jasāo as 'súplicas encantatórias' (litas epaoidas, 217) que levaram Medeia a perder a sua aidos perante os progenitores e favorecer, com a sua magia, o estrangeiro por quem se apaixonara, motivo táo próximo da tradiçāo do conto popular ${ }^{(13)}$. Ambos trocam promessas de uniăo em doce casamento (gamon glykyn, 223-224) e é desejo da jovem seguir Jasão até à Hélade. Quanto ao protagonismo na morte da serpente, ele cabe ao herói, condutor da empresa, como é de esperar pelo próprio contexto da ode e do destinatário para quem foi composta.

Por outro lado, no séc. V a.C. é conhecido um culto, instituído em Corinto, aos filhos de Medeia, no templo de Hera Acraia — culto com carácter reparador pela morte das crianças às máos dos Coríntios ${ }^{(14)}$. Eurípides combina a tradiçăo do culto atribuindo-lhe, no entanto, outra etiologia, com a versão da tradiçáo que conta com a morte de Creonte e sua filha, e o peso, ponderado por Medeia, da fúria dos habitantes de Corinto sobre os seus filhos. Esta versāo, bem como a da morte das crianças por erro da mãe, ao querer conferir-lhes a imortalidade, implicaria, certamente, a ruptura do casal.

Por seu turno, a presença de Medeia em Atenas é já do conhecimento de Heródoto (7. 62). Inovação de Eurípides parece ser, aceitando as conclusôes de Manuwald, a modulaçāo dada ao infanticídio às mãos da própria mãe, na sequência do abandono de Jasăo — decisão gradualmente tomada e nāo ab initio ${ }^{(15)}$ - , bem como o gesto de instituição do culto das crianças mortas, por parte de quem se ergue já para além do humano. Quanto a este ponto, como acabei de referir, Eurípides combinou tradiçōes diversas - aquela que atribui a culpa involuntária da morte das crianças a Medeia, ao ocultá-las no templo de Hera, pensando, com isso, torná-las imortais, e aquela que atribui a sua morte aos Coríntios, por isso castigados com flagelos de origem divina até instituirem um ritual expiatório de compensaçăo pela culpa, no

(13) D.J. Conacher Euripidean Dnama, Toronto, 1967, chama precisamente a atençảo para o facto de ter sido Eurípides quem converteu Medeia de heroína de 'folktale' em protagonista trágica.

(14) Veja-se RE s.u 'Medea'.

(15) H. Erbse entende que o ódio aos filhos é já nítido e determinado no prólogo da peça. Até ao fim deste a decisáo do modo como exercer a vingança está tomada. Entre outros, se pronuncia contra esta perspectiva, com razão, Manuwald —o ódio de Medeia não tem, no início da peça, um objecto definido $\mathrm{e}$ os filhos virăo a ser não objecto mas meio de retaliação. 
templo de Hera Acraia ${ }^{(16)}$. Euripidiano é também o tratamento da presença de Egeu em Corinto (17), abrindo a pólis ateniense ao acolhimento da suplicante, em contraste com as figuras que representam o poder em Corinto, ou dele estăo próximas. É no contexto desta inovação da acçăo trágica que a ethopoiia ganha contornos e, com ela, a reflexâo sobre as razōes que levaram o poeta a construir a acçấo trágica consoante a construiu e, a partir daí, os caracteres que nela estấo envolvidos.

Este prólogo enquadra-se numa das variantes estruturais que encontramos nos prólogos euripidianos, conforme os analisa Erbse (18): combina um monólogo inicial, com um diálogo que se lhe segue e que ilustra, desenvolve e fundamenta as informaçōes e suspeitas apreendidas no monólogo ${ }^{(19)}$. O facto de Eurípides ter escolhido, para a proferir parte expositiva do prólogo, uma figura humana, ligada à intimidade de Medeia, permite que a sua rhesis esteja marcada por um forte tom emocional de quem acompanha e vive, numa posição de proximidade afectiva e de subordinaçāo, o sofrimento daquela mulher. Essa figura é a Ama. O diálogo que se segue a esse monólogo envolve uma outra figura da constelação do oikos nobre e possuidor de descendência: o Pedagogo.

Trata-se, assim, de duas personagens fortemente ligadas a Medeia: a Ama e o Pedagogo. Pela sua proximidade à protagonista e envolvimento na vida familiar conhecem bem esta mulher, a força do seu carácter e dos seus afectos. A figura da Ama pertence, por tradiçăo e estatuto, ao espaço da sua intimidade de protagonistas femininas; o Pedagogo, em contrapartida, por via da sua própria funçâo, funciona como o elo de ligaçăo entre o espaço da casa e do exterior: é ele quem acompanha os filhos da princesa da Cólquida e de Jasão. Um e outro, Ama e Pedagogo, fazem, todavia, parte de um oikos que agora se desagrega. E é do interior desse espaço físico do oikos que o grito de raiva e abandono de Medeia se faz ouvir. Jasão, o kyrios, deixou a casa e todos os seus para se agregar, através de aliança nupcial, à família real de Corinto. Esta constelação de personagens, a que se acrescentará um Coro de Mulheres de Corinto,

(16) Sobre as várias versóes da causa e autoria da morte dos filhos de Medeia e Jasăo na tradiçăo mitológica grega veja-se F.M. Dunn, "Euripides and the Rites of Hera Akraia" GRBS $35,1994,101-115$.

(17) Também Néofron conta já com a presença de Egeu em Corinto, mas justificada por um motivo concreto - a procura de solução para a privaçăo de descendência.

(18) H. Erbse, Studien zum Prolog der euripideischen Tragöedien, Berlin, 1984.

(19) Para uma análise do prólogo veja-se também M.H. Rocha Pereira, op. cit., 12-13. 
permite sublinhar que, além do mais, é no contexto do oikos destruído que o drama de Medeia tem lugar. Pouco a pouco se verá que esse oikos foi destruído por se situar à margem do poder.

Se a proximidade da Ama a Medeia possibilita ler no comportamento da sua senhora sinais que suscitam apreensão pelo que esta possa fazer, essa mesma proximidade permite-lhe compreender que aquele temperamento, capaz de excessos inusitados pela força da paixăo, a que tudo sacrificou, é inclusivamente, também, capaz de dominar a sua natureza fogosa e os seus rasgos de autonomia, num esforço por se enquadrar dentro dos parâmetros do estatuto da esposa grega, "procurando agradar aos cidadáos da terra a que chegou, na sua fuga, em perfeita consonância com Jasāo" (v. 12-13). Bem aceite pelos habitantes de Corinto, o par estreita laços de amizade com a comunidade que o acolhe, consoante o regista o Coro em 136-138 ("uma casa a que me unem laços de amizade" (20)). Foi, pois, após todo um passado de excessos e de crimes por paixáo (Medeia fora "ferida no seu intimo pelo amor por Jasāo", v. 8), um oikos 'normal' que se estabeleceu em Corinto $\mathrm{e}$ af ganhou respeitabilidade por parte dos cidadāos.

É, deste modo, extremamente significativo que Eurípides tenha optado por dar vida a um coro feminino, que pode sentir e sintonizar com o pathos da protagonista, de habitantes de Corinto. Enquanto tal, estas mulheres representam o pensar e sentir dos habitantes da cidade, gratos para com Medeia, ligados à sua casa pela amizade e marcados por uma compaixẩo que os distancia de Jasão e do universo a que Jasão se associou. Deste aspecto me ocuparei mais adiante.

Medeia, no primeiro dos monólogos que profere, ao sair do palácio, no iń́cio do episódio I, deixa ver em si uma mulher que, pela força de eros, luta por contrariar a sua natureza indómita e o seu thymos excepcional. Para poder seguir o seu amado e permanecer com ele, em harmonia, integrada no universo que é o dele, sem dissonância com as normas e costumes aí vigentes, Medeia deu-se a um enorme e verdadeiro esforço de aculturaçāo. Consoante reconhece, "força é que um estrangeiro sintonize com a naçăo" (v. 222).

Foi, pois, como estrangeira e como mulher que Medeia defrontou a dupla dificuldade de tentar integrar-se, contra a sua própria natureza, no contexto do apertado estatuto que espera a mulher, ainda que grega de

(20) Nota, de resto, P.E. Easterling , "The Infanticide in Euripides' Meded", YCS 25, 179 sqq. que Medeia fala, sente e argumenta como uma grega. 
nascimento, na sua nova casa, junto do companheiro, e compreendê-lo, isto é, entrar "em novos costumes e novas leis"; a princesa perita em magia tentou, como as demais mulheres, levar a cabo a difícil tarefa de "ser adivinha, sem ter aprendido em sua casa como lidar devidamente com o companheiro de leito (syneunetes)" (238-240).

O que constitui tarefa difícil para a mulher da Hélade, torna-se ainda mais difícil no caso de Medeia, pela disparidade de códigos culturais, de comportamento e de natureza. Ao sujeitar-se ao estreito espaço de aç̧áo a que é votada a mulher grega, para o caso a mulher casada, Medeia seguiu o imperativo dos sentimentos que a uniam a Jasão e que levaram o par a selar a sua uniāo com juramentos de fidelidade. É essa a base, sobre a qual entendeu construído o oikos, que agora se desmorona - essa casa, consoante a Ama o reconhece, já não existe (v. 139), trocada que foi pela união de um outro leito.

Seja qual for a validade de um casamento entre um grego e uma estrangeira, à data em que a peça foi composta, não é aí que reside o cerne da questão. Por um lado, a acçáo remonta a um tempo mítico-heróico que, consoante já foi notado, predispōe o público a uma apreensāo das relaçôes entre personagens algo liberta de um vínculo rígido à realidade jurídica do tempo histórico da representação. Por outro lado, aquilo que, desde o início da peça, como se depreende das palavras da própria Ama, está em causa, para Medeia, é a questão fundamental, de ordem ética, do compromisso celebrado entre o par, por juramento, e selado pela entrega e pela uniāo conjugal no leito.

Ainda que o motor que levou ao compromisso haja sido a força imbatível de eros e nāo o acordo entre famílias, é na quebra de compromissos, selados pela confiança mútua, que Medeia insiste, nas inflexóes que o seu coraçăo vai conhecendo, do desespero à cólera desmedida. Concorda a sensibilidade da princesa bárbara com o enaltecimento, tecido por Apolo, em Euménides, do carácter sagrado do mais forte dos pactos - pistomata - baseado na confiança mútua, garantido por Zeus e Hera, movido por Cípris e selado no tálamo (Eu. 213 sqq). É este, em Ésquilo, o fundamento que confere solidez ao oikos, célula do edifício da pólis. Também nesta a harmonia de convívio e construçāo da vida em comunidade se pauta por compromissos de fidelidade, assentes na consciência e no sentido da koinonia.

$\mathrm{O}$ oikos fundado por Jasăo e Medeia, por muito forte que seja a gratidāo dos Coríntios à princesa, nâo conhece a integraçăo plena em Corinto, como se percebe pelas próprias palavras do Argonauta. Nâo desempenha, pois, a funçāo da família na construçăo da cidade ideal de 
Euménides. Nẩo deixa, por isso, de ser fulcral, e bem expressiva, de resto, a sensibilidade desta mulher estrangeira à noçáo de vínculo estabelecido por compromissos solenemente selados com o estreitar mútuo da mão direita. São esses juramentos quebrados que levam Medeia, em raiva $\mathrm{e}$ desespero, a clamar no interior da casa, consoante o relata a Ama.

Tanto a Ama, como o Pedagogo, ou o Coro reconhecem, ainda antes que Medeia saia do palácio, que aquela casa foi destruída nos seus fundamentos pelo gesto de Jasão (vv. 136- 143).Do abandono de antigos laços (palaia kedeumaton, 75) por quem já não é amigo (philos) daquela casa fala o Pedagogo. É, pois, para além do drama da traiçáo amorosa e do abandono, o da quebra de vínculos mutuamente assumidos que levam Medeia do desespero à revolta e à disposição de vingança que colhe, à partida, o apoio do Coro de Coríntias.

No kommos que constitui o párodo, e que Eurípides concebeu como um emotivo jogo dialógico entre a orquestra, a cena e aquela que no edifício cénico se oculta -Medeia, no interior do palácio-, ganha particular expressividade a alusāo aos juramentos quebrados pelo "esposo maldito" (vv. 62-63), a tudo o que Medeia sacrificou, com crueldade, por esse amor, e ao espaço material $\mathrm{em}$ que este particular vínculo se consuma - o leito da uniáo.

As referências ao carácter inviolável do juramento, ao que significa, entāo, quebrá-lo, ao leito, espaço de amor consumado, de uniāo vinculativa, de solidāo e amargura em tempo de abandono, convertem-se num motivo fulcral de referência, não só na boca de Medeia mas também na daqueles que a circundam $-\mathrm{o}$ Coro evoca o anandron lektron, o "leito de onde o homem está ausente' (436). Por isso o Coro adopta a perspectiva de Medeia, amaldiçoando o esposo perjuro, ansiando pela vingança - cuja dimensão náo adivinha - e pela queda de quem infringiu valores éticos ideais do universo grego (439-440):

Do juramento se evolou a lealdade; na vastidāo da Hélade a vergonha (aidos) se dissipou nos ares.

O motivo do tálamo desdobra-se no do novo leito, honrado por Jasāo (kaina leche, 156), no da infidelidade ao leito, por parte de um marido criminoso, consoante o próprio Coro o afirma, em sintonia com a protagonista (ton en lechei prodotan kakonymphon, 206), no da dificuldade da mulher, em geral, em reconhecer os costumes e normas do oikos em que entra e em falar a linguagem do seu 'companheiro de leito' (syneunetes, 240). 
O mesmo motivo é desvirtuado por Creonte e por Jasáo, que acusam Medeia de agir por despeito de um leito vazio, sinónimo de frustração pela necessidade sexual não satisfeita ${ }^{(21)}$.

Tendo como horizonte o vínculo, pelo juramento, de duas pessoas que celebram um pacto de confiança mútua, compreende-se que já o Coro, no párodo, invoque Zeus, a Terra e a luz (depreende-se do Sol) e manifeste a sua confiança e expectativa de intervençăo justiceira de Zeus (v. 158) e que Medeia comece por invocar a intervençăo de Témis (v. 160), a par, também, da de Zeus, no que é secundada pela Ama (vv. 168-170) (22). É que a capacidade humana de assumir vínculos contratuais, assentes na disposiçáo de confiança e fidelidade recíproca, é sinal, desde cedo, de competência civilizacional ${ }^{(23)}$. Convocar os deuses a testemunhar tal compromisso, normalmente acompanhado de sacrifícios animais, fala pela própria solenidade dos elos que se tecem e pela sua relação a uma ordem que transcende o homem. Já na Iliada Zeus é invocado por Agamémnon como testemunha dos juramentos, a par da Terra e do Sol, e punidor dos perjuros (Il. 3. 276-280):

"Zeus pai que reges do Ida, gloriosísimo, máximo!

E tu, ó Sol, que tudo vês e tudo ouves!

E vós, ó rios, e tu, Terra, e vós que nos infernos

Vos vingais dos homens mortos, que com perjúrio juraram!

Sede vós testemunhas, vigiai os leais sacrifícios!

Se um traço característico do comportamento ideal do Grego, como homem idealmente civilizado, consiste em honrar os compromissos selados, esta Medeia tem a esperar, de um Jasão por quem sacrificou, por quem traiu, como ela mesma diz ${ }^{(24)}$, selvaticamente tudo o que constituia

(21) E. Bongie, op. cit., p. 44, chama a atençăo para o expressivo desvirtuar da dimensăo significativa de lechos na boca de Jasĭo.

(22) Témis, deusa tutelar de uma justiça divina e da ordem das coisas, é encarada já em Homero, como deusa das assembleias, mas também da ordem familiar (Od. 2. 66-68), é invocada por Medeia, no v. 160, como guardiã da mais solene das promessas.

(23) Veja-se W. Burkert Religião grega na época classica e arcaica, Lisboa, Fundaçăo Calouste Gulbenkian 1993 [trad. do orig. alemäo (1977) Griechische Religion in der klassischen und archaischen Epochen, Stuttgart, Berlin, Köln, Mainz, Verlag W. Kohlhammer GrubH]. pp. 478-485. Nota o insigne helenista que em sociedades $\mathrm{em}$ que a escrita nấ é ainda prática corrente, esta forma de selar verbalmente compromissos solenes mantém uma força poderosissima. A medida que a escrita e o registo documental tendem a tornar-se prática comum de uma cultura, o contrato selado por juramento tende, também a assumir a forma de registo escrito. Veja-se também Rocha Pereira, op. cit., pp. 20-21 sqq.

(24) Veja-se Friedrich, op. cit. 
o seu universo anterior — casa, riqueza, aidos, possibilidade de regressar à pátria antiga - o respeito pelos laços assumidos, se năo pela força de eros, no que a ele toca, pela força da gratidāo.

Frente a um Jasẫo que tenta minimizar o seu gesto e subverter a situaçăo, Medeia fala, de novo, do significado do pacto que no leito é selado e da quebra desse pacto como traição (vv. 488-498). É um perjuro que Medeia sente ter diante de si, com a agravante de ter quebrado, também, o sagrado dever de grata reciprocidade de um suplicante outrora atendido e auxiliado:

E tu, depois de teres recebido esses benefícios da nossa parte, como o mais torpe dos homens nos atraiçoaste e procuraste um novo leito, apesar de teres filhos (...)

(...) Dissipou-se a fé nos juramentos e nem posso saber se crês que os deuses de então já não governam ou que existem agora novas leis para os homens, uma vez que tens consciência do teu perjúrio em relação a mim. Ai, minha mâo direita, quantas vezes a apertaste, e estes joelhos, como em vão se agarrrou a eles, como suplicante, um homem pérfido!

A traiçăo que Medeia reconhece ter cometido para o seu pai e a sua casa, por Jasão, por prothymia mais que por sophia, recebe agora, como recompensa, a quebra do próprio vínculo de súplica. É que ao contrário do que ocorre com a figura de um Jasăo heróico, exterminador de monstros, consoante o apresenta Píndaro, este Jasāo euripidiano logrou conquistar o Velo de Ouro através da acção de Medeia, a verdadeira autora da morte do dragão (vv. 480-482).

No confronto entre as duas figuras, a argumentação de Jasăo antecipa a perícia de uma retórica deformadora dos factos, típica do Grego, no seu retrato negativo, perante a vítima bárbara, como, por exemplo, a de Ulisses frente a Hécuba, na peça homónima, ou a de Helena, também frente a Hécuba, em Troianas ${ }^{(25)}$. Foi Cípris, foi Eros o motor dos gestos de Medeia —nenhuma gratidão há, pois, a vincular o Argonauta; é antes Medeia quem deveria estar grata pela sua vinda para a terra da justiça e das normas reguladoras.

O motivo do leito é subvertido por Jasāo, como já foi notado (26), apontando este, na revolta de Medeia, o despeito pela privaçáo erótica e o

(25) Sobre a perspectiva crítica do binómio Grego-Bárbaro em Eurípides, e em particular nesta peça, veja-se para além do citado trabalho de Friedrich, S. Saìd, "Grecs et barbares dans les tragédies d'Euripide. La fin des différences?" Ktema 9, 1984, 27-53.

(26) Vide supra n. 21. 
ciúme pela troca de companheira para os prazeres do amor. Assim havia Creonte lido também a razão para a dor e raiva de Medeia ("tu és astuta e perita em muitos artifícios, e sofres por te ver privada de um homem no teu leito" vv. 285-286). Todavia, nem o Coro acredita nos argumentos de Jasāo (vv. 576-578):

Jasăo, enfeitaste bem as tuas palavras; a mim, no entanto, parece-me, ainda que me exprima contra a tua opiniẫo, que traindo a tua esposa nấo agiste com justiça.

$\mathrm{O}$ confronto entre ambas as figuras e a densidade ou ligeireza com que encaram o espaço em que se sela a intimidade dos esposos evidencia o abismo que as separa. Para Medeia, tanto a uniăo como o que a ela levou e dela decorreu implicam essa ética de dedicaçăo, assente na reciprocidade - philia - com todo o excesso que marca o seu carácter, a sua natureza ${ }^{(27)}$. Constitui princípio fundamental da ética grega honrar e favorecer os philoi, perseguir os inimigos — nâo apenas os inimigos próprios, mas também aqueles que prejudicam os philoi.

De um modo extremo, como a própria reconhece, aplicando o termo 'trair', Medeia sacrifica os vínculos com a sua comunidade de origem, com a sua família e a sua pátria, por Jasão. Ế ainda por Jasão que aniquila impiedosamente os rivais políticos deste, já em solo grego, como é o caso de Pélias. Assim, é a quebra de todo um código ético, não de cariz 'bárbaro' mas de expressão grega, que Medeia denuncia frente a Jasão, frente àquele que, invocando a sua superioridade civilizacional (vv. 536544), é capaz da anaideia (v. 472) de olhar na face os amigos (philous) a quem traiu e maltratou (v. 470).

Que Jasão tente subverter o argumento da philia traída e demonstrar que o novo casamento —o novo leito (vv. 555.556) — representa, apenas, uma aliança por interesse para prover às necessidades da antiga família, pois "todo o amigo (pas philos, v. 561) foge de que é pobre", só atesta a hipocrisia da personagem, o esvaziamento do seu código ético, e denuncia os interesses que tenta ocultar no seu discurso.

$\mathrm{O}$ recurso argumentativo a valores gregos, por parte daquele que os desrespeita por completo, frente à estrangeira agora abandonada, que denuncia tais contradiçōes, constitui um motivo que se virá a perceber,

(27) Este assunto foi por mim desenvolvido num outro contexto: "O motivo da philia na Medeia de Eurípides"a publicar em A Antiguidade Cldssica e nós: herança e identidade cultural. Actas do colóquio de Estudos Clássicos, Braga, Universidade do Minho. 
cada vez mais, típico da dramaturgia euripidiana. O Argonauta enquadrase, afinal, dentro desse padrāo esvaziado de philia, ao transferir a sua aliança de quem é, no momento, menos favorecido, para quem the promete acesso ao poder. Ao tentar compor e impor o seu ethos de orador, como sophos (v. 548) e sophron (v. 549), sustentando uma bizarra forma de ser megas philos (v. 549) em relação àqueles que abandona, Jasão subestima e acicata o discernimento e a sophia de Medeia, posta ao serviço da mais terrível das vinganças sobre a mais afrontosa das ofensas ${ }^{(28)}$. Passou o tempo em que era oportuna a aliança com a princesa bárbara e agora, como ela mesma o denuncia, em palavras de amargo desencanto, já nấo há glória que advenha de um barbaron lechos (v. 591). O Coro antevê terríveis consequências da "discórdia lançada de amigos contra amigos" (philoi philoisi v. 520).

Por outro lado, também o compromisso selado pelo gesto de súplica do Argonauta, como Medeia o evoca (496-498), outrora atendido e salvo pela princesa, foi quebrado, sem respeito às leis sagradas de que também Zeus é guardião, como Xenios e Hikesios. É esse o verdadeiro sentido da amarga invocaçấo de Medeia à sua mão direita, outrora unida à direita de Jasão em sinal de compromisso e de súplica atendida ${ }^{(29)}$.

Jasão sabe o quanto o seu comportamento infringe os padrōes éticos e procura disfarçá-lo com o cinismo da justificaçáo da sua vinda (459-462):

Venho, no entanto, depois disto, sem me subtrair aos amigos (philois), olhando por ti, mulher, para que tu não saias daqui com os filhos ${ }^{(30)}$, na miséria e na privaçăo.

Medeia pode estimar a dimensão de hipocrisia deste cuidado anunciado quanto a ela e quanto à salvaguarda do destino dos filhos por parte de Jasão. As cenas antecedentes do drama bastam para a elucidar. Medeia representou outrora o acesso ao Velo de Ouro; Glauce representa agora o acesso ao poder em Corinto, pela aliança com o oikos governante.

Percebe-se, assim, que o espaço de Corinto se cinde em duas realidades —a dos seus habitantes, destituídos de poder mas sensíveis aos

(28) Para uma esclarecedora leitura de sophia, na peça, veja-se J.A. López Férez, "Nueva lectura de sophia -sophós en la Medea de Eurípides" in: A. López-A. Pociña (eds.) Medeas. Versiones de un mito desde Grecia hasta hoy, vol. I, pp. 211-232.

(29) A simbologia expressiva da mão direita e dos seus gestos, evocados na peça, é estudada por S. Flory, "Medea's Right Hand: Promises and Revenge" TAPhA 108, 1978, 69-74.

(30) Também o original grego regista a significativa ausência de um possessivo para 'filhos'. 
valores éricos, representado pelo Coro feminino, e a dos poderosos ou daqueles que tentam, calcando fidelidades, associar-se ao poder. Perante a quebra do código ético que liga Jasāo a Medeia, a princesa da Cólquida reconhece nele, agora, um inimigo, exacerbada a sua sede de vingança pelo abandono amoroso, pela gratuidade dos seus gestos de dedicação apaixonada, e pelo seu próprio thymos, antes domado por vontade própria e agora reavivado - um thymos desmedido, incontível, que náo conhece limite na retaliaçăo.

Medeia há-de atingir, na sua vingança, o amigo de outrora, agora inimigo, naquele cerne, mesmo, onde ela foi ferida — na possibilidade de construção de um projecto de vida com o homem, objecto da sua paixăo, mediante a formalização solene de compromissos, a formação da casa e a perpetuaçāo de descendência ("ninguém me suponha fraca, débil ou passiva: outro é o meu carácter — dura para com os inimigos, benévola para com os amigos" vv. 807-809). A vingança implicará a destruiçăo do inimigo através da destruiçáo da sua nova e da sua antiga casa. Isto é, uma parte de Medeia será também sacrificada. Consoante a protagonista o reconhece, a sua hamartia consistiu em ter abandonado "a casa paterna, confiada nas palavras de um grego" (vv. 800 sqq.).

Será, todavia, um grego — nẩo de Corinto, mas de Atenas- quem atenderá a sua súplica e cumprirá o juramento selado de a receber na fuga: Egeu.

A cena de Egeu, que alguns críticos euripidianos depreciaram, pela presença gratuita do soberano ateniense, parece-me, pelo contrário, revestir-se de uma particular importância no que toca a dimensão política da peça - e não devemos esquecer que, na pólis do séc. $V$, não há representação dramática isenta de significado político.

Não é por acaso que, na sua saudaçăo, Egeu se dirige a Medeia tratando-a por philos, após as últimas palavras entoadas pelo Coro, no estásimo II, de censura a Jasăo (658-662):

Pereça como ingrato aquele que não sabe honrar os amigos, depois de thes franquear entrada num coraçáo puro —esse, para mim, jamais será um amigo.

Retomado o motivo da philia, um profundo contraste se irá estabelecer entre o comportamento de Egeu e o de Creonte e Jasăo. Néofron terá feito Egeu vir em busca de Medeia à procura de solução para a sua casa sem descendência; Eurípides fez sair Egeu de Atenas pelo mesmo motivo, mas a consulta foi feita em Delfos e a procura de um conselho junto do soberano de Trezena. 
É, pois, fortuito o encontro entre Egeu e Medeia, no regresso daquele a Atenas. Egeu pensa, à partida, nada ter a esperar de Medeia. Em contrapartida, é o aspecto da própria Medeia que desperta a atençăo de Egeu sobre uma possível perturbaçáo na sua vida. O relato do seu abandono, as perguntas e comentários de Egeu, num diálogo em que se entrelaçam os temas da philia, do leito e da casa abandonados, conduzem o soberano de Atenas à conclusão indignada de que o Argonauta é um kakos (699) e Medeia à conclusão de que Egeu, ao contrário de Jasão, é homem disposto a zelar por juramentos selados assim como, ao contrário de Creonte, Egeu é homem disposto a dar guarida à estrangeira abandonada.

O espectáculo de uma Medeia, postada em atitude de súplica, contrasta com a memória recente, no espectador, do vínculo de súplica quebrado por Jasăo. O acolhimento prometido por Egeu, grato pela promessa de auxílio de Medeia para os seus males, lembraria, certamente, aos espectadores que Creonte expulsa implacavelmente aquela mulher que, pelas suas artes, fora útil a Corinto, num primeiro momento, conforme o sugere a Ama no monólogo inicial, em referência à fome que grassava naquela terra e a que os sortilégios da princesa bárbara puseram fim.

Só a segurança deste acolhimento permite a Medeia executar a sua vingança até ao fim e fazer perecer a casa de Corinto e a de Jasão, ainda que o preço seja, para si mesma, demasiado alto.

A este episódio se segue o estásimo III, uma das mais belas odes de enaltecimento de Atenas.

$\mathrm{O}$ regresso de Medeia à sua antiga natureza e o distanciamento dos seus traços de humanidade, consumado após o infanticídio, para assumir

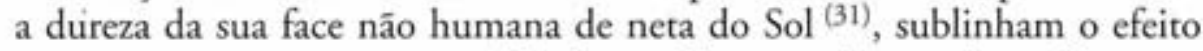
que o comportamento pervertido de um Grego pode ter sobre o Outro, o culturalmente diferente, a quem aquele se apresenta como padráo civilizacional. Năo se trata de todo o Grego, mas das figuras que representam o poder ou a apetência pelo poder em Corinto, por contraste com aqueles que nāo têm, de modo algum, intervençăo deliberativa na vida política desta cidade e que săo representados pelo Coro.

Este tratamento das figuras da constelação do poder em Corinto, por oposiçăo ao do tratamento do soberano de Atenas, ganha particular significado à luz do contexto histórico da representaçăo. Medeia, como comecei por referir, foi apresentada na Primavera do início da Guerra do

(31) Cunningham (apud Rocha Pereira, p. 18) afirma, sobre o carro, que ele é "uma metífora visual da (...) transformaçāo" interior da protagonista. 
Peloponeso, cujo deflagrar há muito era esperado, após o agravar contínuo de conflitos e confronto de interesses económicos que nas mais variadas partes da Hélade se jogavam entre os potentados. Mas se o grande confronto foi liderado, de um e outro lado, por Atenas e Esparta, os Atenienses nāo deixavam de manter a consciência de que um dos grandes motores que accionou as hostilidades foi Corinto, a verdadeira rival de Atenas nas rotas comerciais marítimas.

Consoante o sublinham Blásquez-López Melero-Sayas, era esta a cidade que mais desejava o início das hostilidades e que com mais empenho havia participado, já, nas hostilidades de 460-446, na chamada Primeira Guerra do Peloponeso ${ }^{(32)}$. Já Tucídides, na sua apreciaçâo dos sinais da 'doença' que se anuncia, (1.103) diagnostica, como causas da guerra, o ódio coríntio contra Atenas, cuja expansão da hegemonia marítima encontrara um pilar importante na aliança com Mégara, em 461. O choque de interesses que se jogavam na colónia panelénica de Túrios, a epimaquia com Córcira e o apoio naval de última hora àquela ilha que representava um ponto estratégico importante para a rota comercial no Mediterrâneo a ocidente da Grécia, por fim os incidentes em Potideia, ainda e sempre envolvendo à distância Atenas e Corinto, levam a cidade do istmo a pressionar Esparta para a declaraçáo de guerra de 431.

Para aquém de todos as leituras possíveis da tragédia euripidiana, não podemos deixar de ter em consideração este contexto, no qual o espaço de Corinto se esboça como um espaço trágico de dissonância entre quem detém o poder e quem habita a cidade. Para aqueles nâo são válidos os princípios éticos que marcam a identidade grega e configuram os códigos de comportamento do homem civilizado. Tal infracçăo gera desarmonia, contribui para a exarcebaçấo do thymos da protagonista, para além da sua boa-vontade de aculturação por afecto, e para uma vingança que abala a cidade.

O ritual instituído por uma Medeia ex machina, no final da peça, no templo de Hera Acraia, retoma parcialmente aquela versão da tradiçấo de rituais de compensação instituídos para os Coríntios, de modo a permitirlhes serem expurgados da morte das crianças ${ }^{(33)}$. Aqui, não há expurgaçăo,

(32) Veja-se J.M. Blásquez, R. López Melero, J.J. Sayas, Historia de Grecia Antigua, Madrid, $1992^{2}$, p. 503.

(33) Sobre o ritual e o sacrificio anual de uma cabra negra, junto ao pretenso túmulo dos filhos de Medeia, no temenos do templo de Hera Acraia, em que, cada ano, eram levados a viver sete rapazes e sete raparigas coríntios (o sacrificio da cabra constituia um sacrificio transferencial do dos jovens trajados de negro), veja-se, para além do citado estudo de 
pelo simples facto de que não houve infanticídio por parte da pólis: é a pólis, contudo, sem os seus governantes destruídos e sem Jasāo, ainda mais castigado ao ser-lhe negado providenciar o gesto preceituado do funeral dos filhos ${ }^{(34)}$, que contribuirá para uma rearmonizaçāo de um universo que foi, de qualquer modo, abalado. E deverá fazê-lo sozinha, já que à neta do Sol, outrora benfeitora da cidade, aguarda-a Atenas, pelo juramento selado e cumprido por Egeu, na sequência do qual se acende a luz da esperança para a descendência e continuidade dentro da casa real - continuidade essa destruída na casa real de Corinto.

F.M. Dunn, o excelente artigo de W. Burkert, que inaugurou uma nova perspectiva sobre as próprias possiveis origens da tragédia, "Greek Tragedy and Sacrificial Ritual" GRBS 7, 1966, 119 sqq.

(34) Competia ao kyrios providenciar e dirigir o funeral dos seus familiares. Veja-se R. Seaford, Reciprocity and Ritual. Homer and Tragedy in the Developing City-State, Oxford, 1994, pp. 74-78. 